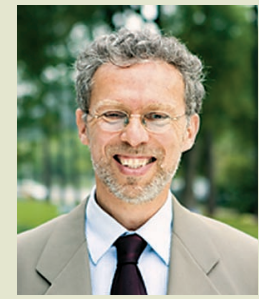

Ricardo Abramovay

FEA/USP abramov@usp.br

\title{
gestão
}

\section{A democracia e o mundo empresarial}

\author{
ORGANIZAÇÕES EMPRESARIAIS PODEM CONTRIBUIR DE MANEIRA \\ ATIVA E VOLUNTÁRIA PARA FINALIDADES DE NATUREZA \\ SOCIAL COMO A PRESERVAÇÃO DO MEIO AMBIENTE, A MELHOR \\ DISTRIBUIÇÃO DA RENDA OU O FORTALECIMENTO DA DEMOCRACIA?
}

Uma poderosa voz vem juntar-se aos que respondem a esta pergunta com um enfático não. Supercapitalism - The Transformation of Business, Democracy, and Everyday Life (Knopf, 2007), o último livro de Robert B. Reich, exministro do Trabalho de Bill Clinton e hoje professor em Stanford, é uma contundente denúncia do poder sem limites que as grandes corporações conquistaram em todo o mundo.

Para Reich, a noção de cidadania não se aplica às empresas e o capitalismo contemporâneo, longe de fortalecer a descentralização do poder a que o mercado deveria conduzir, está, ao contrário, concentrando a riqueza e destruindo a capacidade de interferência pública nos negócios. Reich vê um inevitável conflito entre investidores e consumidores, por um lado, e cidadãos, por outro.

Para ele, não faz sentido esperar que as empresas tenham preocupações que extrapolem a obtenção de lucros para seus acionistas e o sucesso de seus executivos. Os problemas sociais provocados pelo capitalismo devem ser enfrentados no plano da política, pelo fortalecimento da democracia e não pela ação empresarial. Acreditar na responsabilidade socioambiental das empresas não passa de cortina de fumaça.

Por mais importante e construtivo que seja o apelo de Robert B. Reich ao fortalecimento da democracia e da participação dos cidadãos nos negócios públicos, há um problema sério em seu raciocínio. A economia e o mundo empresarial são apresentados como se estivessem acima das instituições sociais, como se recebessem apenas os sinais de indivíduos desejosos de lucros. É cada vez maior, porém, a influência de uma importante corrente do pensamento social contemporâneo - a nova sociologia econômica -, que procura apresentar os próprios mercados sob um ângulo político-cultural e não estritamente econômico.

As empresas e os mercados em que atuam estão mergulhados na realidade social e é extremamente importante que Organizações Não Governamentais procurem influenciar diretamente as práticas empresariais não apenas no sentido do cumprimento da lei, mas no de acompanhar as conseqüências daquilo que fazem para a sociedade e o meio ambiente.

Dizer que isso é irrelevante ou ilusório significa preconizar um recuo a atitudes ainda incipientes, mas promissoras, pelas quais o mundo empresarial começa a elaborar parâmetros em que a avaliação de suas práticas vai além dos números publicados em seus balanços. Os limites entre o mundo dos negócios, a sociedade e a política não estão, felizmente, traçados de antemão, mas são permanentemente reconstruídos por meio dos próprios conflitos sociais. A empresa, neste sentido, também é parte da construção democrática. ^ 